\title{
Current Ratio (CR) dan Return On Equity (ROE) terhadap Earning Per Share (EPS) Studi Kasus PT. Wijaya Karya Tbk
}

\author{
Achmad Agus Yasin Fadli ${ }^{1)}$; Amthy Suraya ${ }^{2)}$ \\ ${ }^{1,2)}$ Dosen Universitas Pamulang, email. dosen00949@unpam.ac.id ; dosen00627@unpam.ac.id
}

\section{ARTICLES}

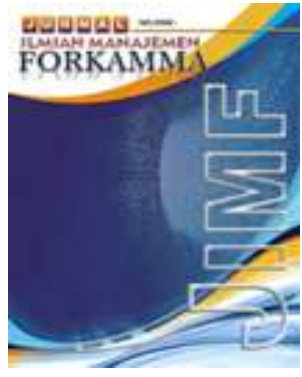

\section{JURNAL ILMIAH MANAJEMEN FORKAMMA}

\section{Vol.3, No.2, Maret 2020 Halaman : $170-183$ \\ (c) LPPM \& FORKAMMA}

Prodi Magister Manajemen UNVERSITAS PAMULANG

ISSN (online) : 2599-171X ISSN (print) : :2598-9545

Keyword :

Current Ratio (CR) ; Return On Equity (ROE ; Earning Per Share (EPS)

JEL. classification : O15,

Contact Author :
PRODI
MAGISTER MANAJEMEN \&
FORKAMMA UNPAM
JL.Surya Kencana No.1 Pamulang
Tangerang Selatan - Banten
Telp. (021) 7412566, Fax (021) 7412491
Email :
jurnalforkamma.unpam@gmail.com

Penelitian ini bertujuan untuk menganalisis dampak dari koefisien saat ini (CR) dan return on equity (ROE) terhadap earning per share (EPS) untuk periode 2011-2017 PT Wijaya Karya Tbk, yang terdaftar di bursa efek Indonesia. (BEI)

Data yang digunakan dalam penelitian ini adalah data sekunder dari laporan keuangan tahunan perusahaan yang diterbitkan di www.idn.financials.com. / www.idx.com. Metode analisis data yang digunakan: analisis kuantitatif, uji statistik deskriptif, uji hipotesis klasik dan uji regresi linier berganda.

Hasil penelitian menunjukkan bahwa rasio lancar (CR) memiliki dampak yang signifikan terhadap laba per saham (EPS). sedangkan laba atas ekuitas (ROE) sebagian dipengaruhi tetapi tidak signifikan dalam laba per saham (EPS). dan pada saat yang sama, rasio saat ini (CR) Return on equity (ROE) memiliki dampak signifikan terhadap earning per share (EPS).

The purpose of this study is to analyze the impact of the current ratio $(\mathrm{CR})$ and return on equity (ROE) on earnings per share (EPS). Case Study on PT Wijaya Karya Tbk. 2011 - 2017 period listed on the indonesian stock exchange (IDX)

The data used in this study are secondary data from the company's published annual financial statements. on the page www.idn.financials.com. / www.idx.com The independent variables used in this study are the current liquidity ratio (CR) and return on equity (ROE). while the dependent variable This study uses a company listed on the Indonesian Jakarta Stock Exchange 2011 - 2017. Data analysis methods used are Quantitative Analysis, Descriptive Statistics Test, Classical hypothesis Test, Multiple linear regression test, correlation test, coefficient and hypothesis test with t-test and F-test.

The results showed that the current ratio (CR) partially had a significant effect on Earnings Per Share (EPS), Return on Equity (ROE) has a partial but insignificant effect on earnings per share (EPS). At the same time, the current liquidity ratio $(\mathrm{CR})$ and return on equity (ROE) have a significant impact on earnings per share (EPS). 


\section{A. PENDAHULUAN}

Setiap binis yang mapan harus berusaha untuk menghasilkan laba sebanyak mungkin. Laba adalah laba dari bisnis perusahaan untuk jangka waktu tertentu. Keuntungan hanya dapat dicapai melalui hasil kerja yang baik dari bisnis tersebut. Dan setiap laba yang dihasilkan oleh perusahaan digunakan untuk membiayai semua kegiatan operasional perusahaan, seperti pembayaran gaji karyawan dan biaya lainnya. Dan jika bisnis dapat menghasilkan laba terus menerus, kelangsungan bisnis pasti dijamin. Investor dapat menilai kinerja manajemen bisnis dengan memeriksa laporan keuangan yang dipublikasikan.

Dunia bisnis sedang memasuki era globalisasi telah menyebabkan persaingan yang semakin ketat. Keadaan seperti itu mengharuskan setiap bisnis beroperasi secara efektif dan efisien agar dapat terus memiliki keunggulan kompetitif, sehingga keberlanjutan bisnis tetap terjaga. Faktor-faktor yang mendukung keberlangsungan bisnis adalah ketersediaan modal yang cukup untuk membiayai kegiatan bisnis. Sumber uang murah untuk modal dapat diperoleh dari perusahaan dengan menjual saham kepada publik di pasar modal.

Ukuran dimana investor dapat mengevaluasi efektivitas bisnis mereka adalah jumlah earning per share (EPS). EPS adalah hubungan "pasar" yang memeprlihatkan kemampuan perusahaan menawarkan pengembalian (return) kepada pemilik bisnis. Ketika memperkirakan laba per saham (EPS), tampaknya ada perbedaan dalam temuan penelitian mengenai earning per share (EPS) untuk perusahaan di Indonesia. Ini adalah acara yang menarik untuk dilakukan penelitian. Menurut Fahmi (2011: 138), Penghasilan per saham atau pendapatan per saham adalah bentuk pendapatan saham untuk setiap saham yang tersedia.

Dalam kamus besar Bahasa Indonesia (KBBI), "likuiditas adalah suatu posisi tunai bisnis dan kemampuannya untuk memenuhi kewajibannya tepat waktu, kemampuan untuk memenuhi kewajibannya tepat waktu". Kata likuiditas adalah istilah yang diserap oleh bahasa Inggris yang berasal dari kata liquid, yang berarti liquid. Istilah ini umumnya menunjukkan tingkat pembayaran dana atau kekayaan yang dimiliki organisasi komersial, termasuk bank yang berlokasi di sana.

Menurut Fred Weston yang dikutip oleh Kasmir (2008: 129), rasio likuiditas adalah ukuran yang menunjukkan kemampuan perusahaan untuk memenuhi kewajiban lancar (utang) mereka. Menurut Bambang Riyanto (2010, hal. 25), rasio likuiditas dikaitkan dengan kemampuan perusahaan untuk memenuhi kewajiban keuangannya, yang harus segera dipenuhi. Menurut Syafrida Hani (2015, hal. 121), "rasio likuiditas adalah kemampuan perusahaan untuk memenuhi kewajiban keuangan yang dapat dibayar segera atau lambat".

Rasio saat ini (CR) adalah jenis Rasio likuiditas. Rasio likuiditas adalah indikator utama yang mengukur apakah perusahaan dapat memenuhi kewajiban jangka pendeknya. Menurut Munawir (2005: 72), indikator yang paling umum digunakan untuk menganalisis posisi modal kerja perusahaan adalah indikator saat ini (CR), indikator antara jumlah aset lancar dan kewajiban lancar. Menurut Darsono dan Ashari (2005: 54), Rasio likuiditas saat ini (CR) adalah indikator utama yang menunjukkan seberapa baik aset lancar perusahaan dapat memenuhi kewajiban jangka pendek dengan aset lancar mereka.

Menurut Syafrida Hani, rasio lancar / CR (CR) adalah ukuran Likuiditas, yaitu kemampuan melunasi hutang yang harus segera dilunasi dengan aset lancar. Menurut Syafri Harahap (2013, hal. 301), ukuran saat ini (CR) adalah ukuran yang menunjukkan sejauh mana aset jangka pendek mencakup kewajiban jangka pendek.

Return On Equity (ROE) adalah bentuk profitabilitas. Rasio Profitabilitas. Indikator profitabilitas adalah indikator yang menentukan kemampuan perusahaan untuk menghasilkan laba dari pendapatan (pendapatan) yang terkait dengan penjualan, aset, dan ekuitas berdasarkan penilaian tertentu. Return on Equity (ROE) adalah metode lain untuk mengukur profitabilitas perusahaan. "Return on Equity (ROE) secara eksplisit menganalisis pengembalian perusahaan atas pemegang saham biasa. Ini berarti bahwa bunga dan dividen dimasukkan dalam analisis. Keuntungan perusahaan biasanya didistribusikan di antara pemegang saham, seperti hutang, saham preferen dan saham biasa". 
Return on Equity (ROE) mengukur kemampuan perusahaan untuk menghasilkan pengembalian yang wajar bagi para pemegang sahamnya. Rasio ini dipengaruhi oleh tingkat utang perusahaan. Jika bagian utang perusahaan lebih tinggi, rasio ini juga lebih tinggi.

Menurut Agnes Sawir (2001: 20), Pengembalian modal didefinisikan sebagai ukuran sejauh mana perusahaan mengelola modalnya sendiri (Networth), pengembalian investasi pemilik atau pemegang saham.

Menurut Gibson (1996: 429), "laba per saham adalah rasio yang mewakili laba per saham. Sementara itu, menurut Weygandt et. et al". (1996: 805-806) dan Elliot (1993: 250) mengukur laba per saham, laba bersih yang diperoleh dari setiap saham biasa. Salah satu alasan investor membeli saham adalah karena mereka mendapatkan dividen. Ketika laba per saham rendah, perusahaan juga cenderung membayar dividen. Dengan demikian, kita dapat mengatakan bahwa investor lebih tertarik pada laba tinggi per saham daripada laba rendah per saham. Laba per saham yang rendah cenderung menurunkan harga saham.

PT Wijaya Karya (Persero) Tbk (WIKA) adalah salah satu perusahaan konstruksi di Indonesia. Menurut hasil nasionalisasi perusahaan Belanda Naamloze Vennotschap Technische Handel Maatschappij dan Bouwbedijf Vis en Co atau NV Vis en Co berdasarkan Keputusan Pemerintah No. 2 tahun 1960 dan Keputusan Menteri Pekerjaan Umum dan Energi (PUTL) n 5 WIKA lahir pada tanggal 11 Maret 1960 dengan nama Negara. Negara Gedung Vijaya Kardja.

Sebagai subkontraktor, WIKA menjadi wirausahawan pada akhir 1960-an untuk pemasangan jaringan tegangan rendah, sedang dan tinggi. Pada awal 1970-an, WIKA memperluas kegiatannya menjadi kontraktor dan kontraktor konstruksi tubuh.

Perusahaan memasuki fase baru pada 20 Desember 1972. Berkat tindakan ke-110, yang diambil sebelum notaris Jojo Muliadi, perusahaan mengubah statusnya menjadi Vijaya Karya (Terbatas). WIKA masih membuat terobosan. Menjadi perusahaan infrastruktur terintegrasi dengan menciptakan beberapa anak perusahaan. Ini termasuk WIKA Beton, WIKA Intrade dan WIKA Realty. Pertumbuhan WIKA sebagai perusahaan infrastruktur yang sangat terintegrasi semakin diakui oleh berbagai pihak. Pada tanggal 29 Oktober 2007, perusahaan berhasil menyelesaikan IPO 35\% di Bursa Efek Indonesia. Setelah IPO, Pemerintah Republik Indonesia memiliki 68,4\%, dan sisanya dari Program Manajemen Inventaris (MSOP), yang didistribusikan kepada publik, termasuk karyawan, termasuk saham karyawan (ESA) dan opsi saham untuk karyawan / manajer (E. / MSOP) .

Akuisisi IPO baru akan digunakan untuk mendukung pertumbuhan dan inovasi WIKA. Posisi WIKA menguat ketika krisis ekonomi global terasa di Jerman. Struktur modal yang kuat sangat mendukung WIKA dalam memperluas kegiatannya di luar negeri dan terus mengembangkan teknologi pengadaan dan konstruksi (EPC), serta berinvestasi dan berinvestasi dalam sejumlah proyek infrastruktur, khususnya, proyek yang menjadi program negara sehubungan dengan anggaran negara (APBN) . )) dan anggaran daerah (APBD). Akuisisi IPO baru akan digunakan untuk mendukung pertumbuhan dan inovasi WIKA. Posisi WIKA menguat ketika krisis ekonomi global terasa di Jerman. Struktur modal yang kuat sangat mendukung WIKA dalam memperluas kegiatannya di luar negeri dan terus mengembangkan teknologi pengadaan dan konstruksi (EPC), serta berinvestasi dan berinvestasi dalam sejumlah proyek infrastruktur, khususnya, proyek yang menjadi program negara sehubungan dengan anggaran negara (APBN) . )) dan anggaran daerah (APBD).

\section{B. KAJIAN LITERATUR}

\section{Manajemen}

Gestion berasal kata lama bahasa Prancis "gestion", yang berarti menerapkan dan mengatur. Manajemen berasal dari kata kelola, yang berarti regulasi. Perjanjian dibuat sepanjang proses dan diatur sesuai dengan urutan fungsi manajemen.

Manajemen adalah seni dalam mencapai tujuan organisasi dengan pengordinasian sumber daya mulai dari perencanaan, pengorganisasian, kepemimpinan, dan pengendalian untuk mencapai tujuan tertentu sehingga dapat terselesaikan secara efektif dan efisien.

\section{Manajemen Keuangan}

Manajemen keuangan termasuk penggalangan dana, penggunaan dana dan manajemen aset yang efektif sesuai dengan tujuan bisnis . 


\section{Laporan keuangan}

Dalam praktiknya, laporan keuangan tahunan perusahaan tidak dipesan secara acak, tetapi harus disiapkan dan disiapkan sesuai dengan aturan atau standar yang berlaku. Ini harus dilakukan agar laporan keuangan mudah dibaca dan dipahami. Transaksi komersial sangat penting bagi manajemen dan pemilik bisnis. Selain itu, banyak pihak membutuhkan dan tertarik pada laporan keuangan perusahaan seperti pemerintah, pemberi pinjaman, investor dan pemasok. (Kashmir, 2014: 6)

Menurut Ikatan Akuntan Indonesia (2012: 5), gelar adalah struktur yang mewakili posisi keuangan dan kinerja perusahaan. Tujuan keseluruhan dari gelar ini adalah minat publik dalam menyajikan informasi tentang posisi keuangan perusahaan, hasil keuangan dan arus kas, yang sangat berguna dalam membuat keputusan ekonomi bagi pengguna perusahaan. , Untuk mencapai tujuan ini, laporan keuangan tahunan harus berisi informasi tentang unsur-unsur perusahaan, termasuk aset, kewajiban, modal, biaya dan pendapatan (termasuk laba dan rugi), perubahan ekuitas. dan arus kas. Informasi ini diikuti Komentar yang memungkinkan pengguna untuk memprediksi arus kas masa depan .

\section{Neraca}

Menurut Munawir (2014: 13), neraca adalah laporan sistematis tentang aset, kewajiban, dan ekuitas perusahaan pada titik waktu tertentu. Menampilkan kondisi keuangan perusahaan pada tanggal tertentu, biasanya ketika pembukuan ditutup dan saldo ditetapkan pada akhir tahun fiskal atau kalender.

\section{Akun Laba Rugi}

Menurut Brealey, Myers dan Marcus (2012: 61), akun laba rugi menunjukkan profitabilitas perusahaan untuk tahun tersebut. Laporan laba rugi adalah laporan keuangan yang menunjukkan pendapatan, pengeluaran, dan laba bersih perusahaan untuk periode waktu tertentu .

\section{Arus kas (cash flow statement)}

Laporan arus kas adalah laporan yang merangkum arus kas masuk dan keluar selama periode waktu tertentu. Berguna untuk membantu pengguna laporan keuangan mengevaluasi jumlah dan ketidakpastian arus kas masa depan .

Pernyataan perubahan ekuitas (pernyataan perubahan ekuitas)

Rasio perubahan modal adalah rasio jumlah uang dan jenis modal yang dimiliki saat ini. Selain itu, laporan ini juga menjelaskan perubahan ekuitas dan alasan perubahan ekuitas di perusahaan (Kasmir, 2012: 29). Pernyataan perubahan ekuitas adalah pernyataan jumlah dan jenis ekuitas yang saat ini dimiliki .

\section{Catatan atas laporan keuangan (Notes to Financial Statement)}

Penjelasan dari laporan keuangan di mana prinsip-prinsip akuntansi, perubahan dan komentar pada akun perusahaan dirinci.

\section{Analisis Rasio keuangan}

Menurut Kasmir (2010: 93), indikator keuangan adalah kegiatan di mana angka-angka untuk laporan keuangan tahunan dibandingkan dengan membagi satu angka dengan yang lain. Menurut Irham Fahmi (2016: 49), ukuran finansial adalah studi yang menguji perbandingan jumlah yang diterima dalam laporan keuangan tahunan menggunakan formula yang dianggap representatif. Kinerja keuangan sangat penting untuk menganalisis situasi keuangan perusahaan. Informasi ini dapat lebih mudah diketahui dengan menghitung rasio keuangan yang diinginkan .

\section{Current Ratio (CR)}

Menurut Munawir (2014: 72), Rasio jangka pendek adalah rasio jumlah aset lancar dan liabilitas jangka pendek. Rasio jangka pendek yang terlalu tinggi menunjukkan kelebihan uang tunai atau aset jangka pendek lainnya dibandingkan dengan nilai saat ini atau likuiditas yang lebih rendah daripada aset jangka pendek, dan sebaliknya .

$$
\text { Current Ratio }=\frac{\text { Aktiva Lancar }}{\text { Hutang Lancar }} \times 100 \%
$$




\section{Return On Equity (ROE)}

Menurut Agnes Sawir (2001: 20), Pengembalian ekuitas didefinisikan sebagai indikator yang menunjukkan sejauh mana perusahaan mengelola kekayaan bersihnya (Networth), pengembalian investasi yang dilakukan oleh pemilik atau pemegang saham.

\section{Earning Per Share (EPS)}

$$
R O E=\frac{\text { laba bersih setelah Pajak }}{\text { Ekuitas Pemegang Saham }} \times 100 \%
$$

Menurut Kasmir (2014: 207), laba per saham biasanya disebut sebagai laba per saham dan merupakan indikator keberhasilan manajemen dalam menghasilkan pengembalian bagi pemegang saham.

$$
E P S=\frac{\text { Laba Bersih Setelah Pajak }- \text { Dividen }}{\text { Jumlah Saham Yang Beredar }}
$$

\section{METODOLOGI PENELITIAN}

Penelitian ini adalah deskriptif, kuantitatif, yaitu situasi keuangan suatu bisnis yang disajikan dalam bentuk angka dan digunakan untuk memeriksa populasi dan sampel yang ditentukan dalam penelitian ini.

Sedangkan data dalam penelitian ini diambil data dari PT. Wijaya Karya Tbk . Sebanyak 7 periode yaitu tahun dat 2011 samapai tahun 2017.

\section{Sumber Data}

Data primer

Data primer adalah data yang diterima atau dikumpulkan secara lokal dari orang-orang yang melakukan penelitian berdasarkan laporan keuangan dalam bentuk neraca dan data akun laba rugi dari Bursa Efek Indonesia (BEI) untuk keperluan penelitian di PT. Wijaya Karya Tbk. Laporan keuangan dalam bentuk neraca dan laporan laba rugi digunakan sebagai data utama.

a. Data sekunder

Data sekunder adalah sumber data penelitian yang diperoleh sebagai hasil dari studi statistik untuk memberikan data teoritis dan ilmiah yang dapat digunakan sebagai dasar untuk menganalisis masalah. Data tersebut dalam bentuk dokumen bisnis yang akan

2. Jenis Data diperiksa menggunakan berbagai sumber literatur .

\section{a. Data kuantitatif}

Data berupa angka yaitu laporan keuangan dalam bentuk neraca PT dan laporan laba rugi. Vijaya Karja TBC. Periode 2011-2017.

b. Data berkualitas

Berupa kata, kalimat dan gambar yaitu berupa sejarah PT. Wijaya Karya Tbk. Dan struktur organisasi

\section{Pengumpulan Data}

Dalam penelitian ini, Metode pengumpulan data meliputi:

a. observasi

Surveillance adalah metode pengumpulan data mengumpulkan data dalam bentuk laporan tahunan yang diterbitkan oleh perusahaan dan mengambil data keuangan perusahaan dari PT. Wijaya Karya Tbk. Periode 2011-2017 diperoleh oleh pasar saham, yaitu www.idx.co.id, pengumpulan data dilakukan dengan menyimpan laporan keuangan, laporan tahunan, laporan triwulanan dan laporan terkini atau informasi sosial yang berkaitan dengan perusahaan . 
b. Studi Sastra

Studi literatur adalah studi yang dilakukan dengan mengumpulkan data dan membaca bukubuku ilmiah, dengan mempelajari buku-buku atau referensi seperti: majalah, internet sehubungan dengan masalah untuk belajar. Studi literatur digunakan untuk memperoleh informasi teoritis yang akan dipelajari.

c. Dokumentasi

Dokumentasi adalah sarana untuk merekam data - data atau dokumen lain yang berkaitan dengan masalah yang sedang dipelajari.

\section{HASIL DAN PEMBAHASAN}

\section{Hasil Statistik Deskriptif}

Rasio likuiditas saat ini (CR), laba atas ekuitas (ROE) dan laba per saham (EPS) dipaikai dalam menampilkan banyaknya data $(\mathrm{N})$ yang dipergunakan dalam penelitian ini, dan juga untuk menampilkan average dan standar deviasi setiap variabel penelitian, Anda bisa menggunakan statistik deskriptif. Hasil data statistik deskriptif yang diproses adalah variabel pencarian menggunakan SPSS dan disajikan dalam tabel di bawah ini

Tabel 4.1

Hasil Analasis Deskriptif Data

Descriptive Statistics

\begin{tabular}{|l|l|l|l|}
\hline & Mean & $\begin{array}{l}\text { Std. } \\
\text { Deviation }\end{array}$ & N \\
\hline EPS & 104,7529 & 34,35933 & 7 \\
CR & 1,244057 &, 1743648 & 7 \\
ROE &, 227200 &, 0676081 & 7 \\
\hline
\end{tabular}

Sumber: hasil pengolahan data SPSS.

Dari hasil hitungan di atas, jumlah data $(\mathrm{N})$ yang digunakan adalah 7 data. Variabel $\mathrm{CR}$ rata-rata (rata-rata) adalah 1,244057 dengan deviasi standar 1743648 , dan variabel $\mathrm{ROE}$ rata-rata (rata-rata) adalah 0,22200 dengan deviasi standar 0,076081 sedangkan variabel EPS rata-rata ( berarti) adalah 104,7529 dengan standar deviasi 34,35933.

\section{Uji Asumsi Klasik}

a. Hasil Uji Normalitas

Gambar 4.2

Histogram Uji Normalitas

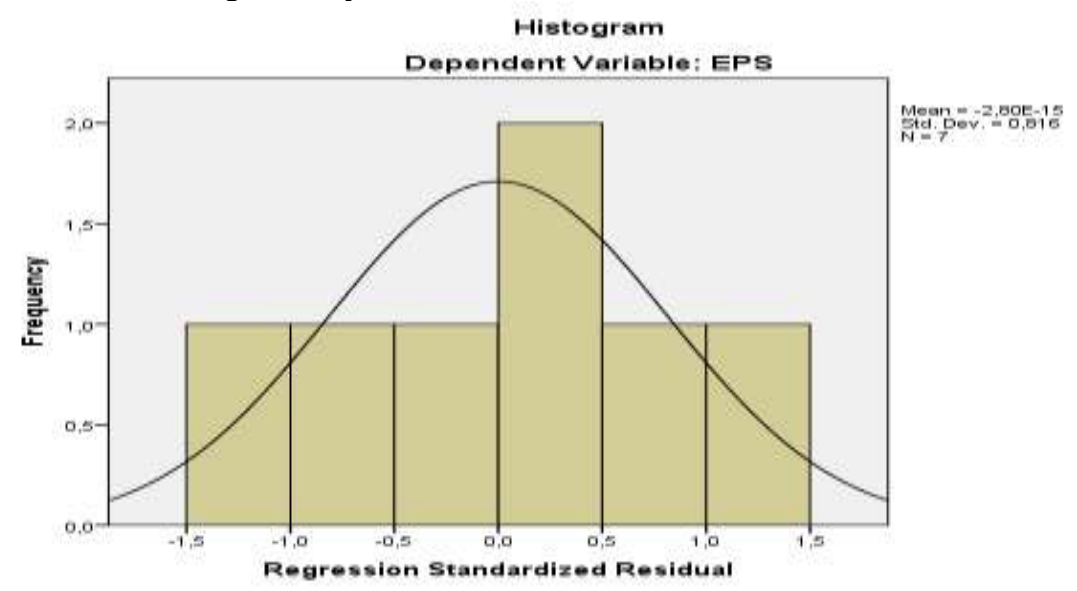

Sumber: data sekunder yang diproses oleh SPSS 
Dari histogram di atas, diketahui bahwa kurva memiliki nilai histogram terdistribusi normal. Hal ini dilihat dari nilai residu terdistribusi "normal", karena pemeriksaan normalitas dilakukan bukan untuk setiap variabel, tetapi untuk nilai residu. Analisis yang lebih rinci menggunakan grafik probabilistik normal residu regresi yang dinormalisasi dapat dilihat pada gambar berikut:

Gambar 4.3

Grafik Normalitas Probability

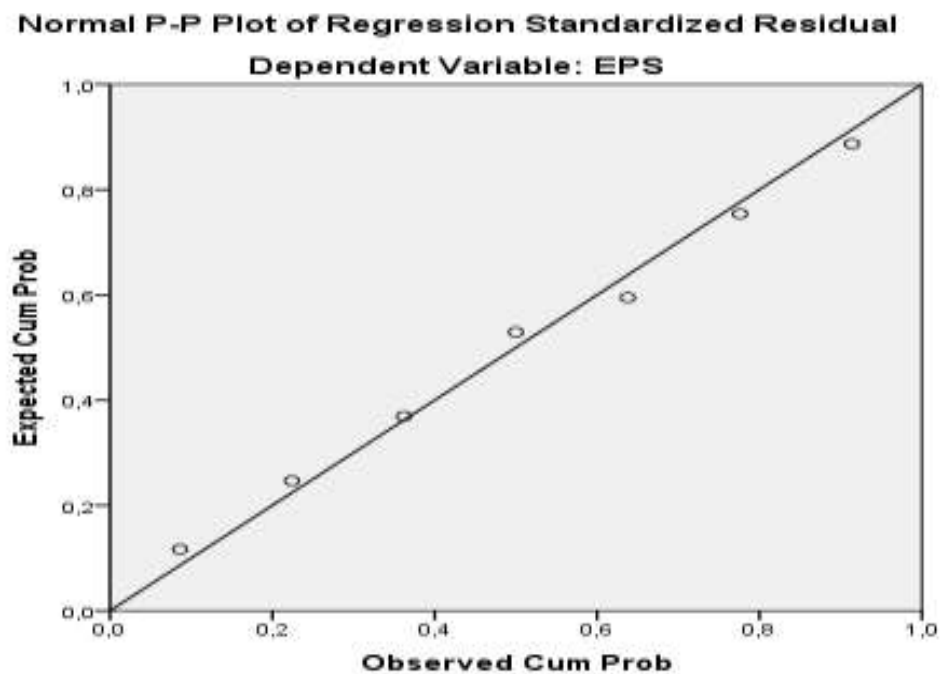

Sumber: data sekunder yang diproses oleh SPSS

Pada Gambar 4.3 di atas, dapat dilihat bahwa titik-titik pada diagram mendekati sumbu diagonal atau hampir bertepatan atau membentuk sudut 45 derajat dengan garis horizontal. Interpretasinya adalah bahwa nilai residual dalam model penelitian biasanya didistribusikan dan regresi memenuhi asumsi konvensional. Untuk meningkatkan hasil tes, tes Kolmogorov-Smirnov digunakan sebagai berikut:

Tabel 4.2

Uji Normalitas dengan Kolmogorov - Smirnov

One-Sample Kolmogorov-Smirnov Test

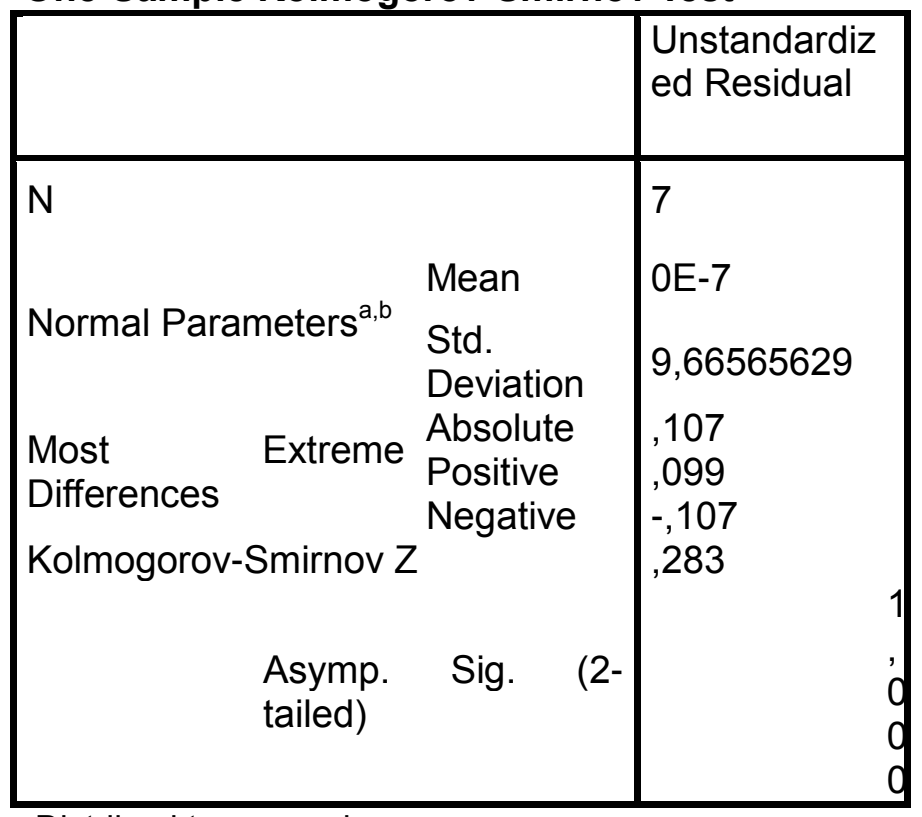

a. Distribusi tes normal.

b. Dihitung menurut data. 
Nilai signifikansi adalah $1000>0,05$, yang menunjukkan bahwa nilai residu biasanya didistribusikan, karena secara teoritis data biasanya disebar ketika signifikansi melebihi 0,05 $(>0,05)$. Secara umum, uji normalitas digunakan untuk menentukan varians dari "nilai dan kemungkinan bahwa nilai mendekati nilai seluruh populasi". Tes ini dapat menunjukkan bahwa sampel yang diambil dapat mewakili populasi. Namun demikian, kita tidak boleh lupa bahwa uji normalitas tidak menentukan survei saat ini, tetapi hanya ingin melihat sejauh mana kekuatan sampel yang diambil dapat mewakili populasi berdasarkan ukuran atau ukuran sampel yang diambil, yang memiliki pengaruh utama pada nilai normalitas.

\section{b. Hasil Uji Autokorelasi}

Self-staining digunakan untuk memverifikasi keberadaan dalam model regresi linier hubungan antara kesalahan penyusup pada periode ( $t$ ) dan kesalahan pada periode sebelumnya ( $\mathrm{t}-1)$, setelah itu deteksi pewarnaan diri dapat digunakan dalam masalah Durbin-Watson. , (D) dengan tabel Durbin-Watson (DU), yang diklasifikasikan dalam model tabel berikut:

Tabel 4.3

Hasil Uji Autokorelasi Dengan Durbin-Watson

Model Summary ${ }^{\mathrm{b}}$

\begin{tabular}{|l|l|l|l|l|l|}
\hline Model & $R$ & $R$ Square & $\begin{array}{l}\text { Adjusted } \\
\text { Square }\end{array}$ & $\begin{array}{l}\text { Std. Error of } \\
\text { the Estimate }\end{array}$ & $\begin{array}{l}\text { Durbin- } \\
\text { Watson }\end{array}$ \\
\hline 1 &, $960^{\mathrm{a}}$ &, 921 &, 881 & 11,83796 & 1,709 \\
\hline
\end{tabular}

a. Predictors: (Constant), ROE, CR

b. Dependent Variable: EPS

Nilai DU untuk 2 variabel dengan 7 data pada 5\% adalah 1,709. Tampaknya $0<$ DW <DU yang termasuk dalam kategori tidak mengambil keputusan Untuk meningkatkan hasil, gunakan uji coba di mana pengguna autokorelasi jika secara signifikan lebih rendah dari 0,05. Ini adalah uji autokorelasi dengan tes kinerja:

Tabel 4.4

Tes autokorelasi Dengan Uji Kinerja Runs Test

\begin{tabular}{|l|l|}
\hline & Unstandardized \\
& Residual \\
\hline Test Value &, 86582 \\
Cases < Test Value & 3 \\
Cases >= Test Value & 4 \\
Total Cases & 7 \\
Number of Runs & 4 \\
Z &, 000 \\
Asymp. Sig. (2-tailed) & 1,000 \\
\hline
\end{tabular}

a. Median

Hasil statistik yang diperoleh dari Runs Test di atas memiliki nilai signifikan $1000>0,05$ karena nilai signifikan lebih dari 0,05, kita dapat menyimpulkan bahwa data tidak menunjukkan masalah autokorelasi atau pelanggaran dalam model. Penelitian atau tidak menanggapi hipotesis autokorelasi klasik.

\section{c. Hasil uji multikolinieritas}

Tujuan dari uji multikolinearitas adalah untuk menentukan apakah model regresi telah menemukan hubungan antara variabel independen. Tidak ada model regresi yang baik. Korelasi antara variabel multikolinearitas independen juga dapat dikonfirmasi oleh nilai toleransi (TOL) dan metode VIF (Variance Inflation Factor). Barang-barang berikut ini dapat muncul pada tabel di bawah ini: 
Tabel 4.5

Hasil Uji Multikolinearitas

\section{Coefficients $^{\mathrm{a}}$}

\begin{tabular}{|c|c|c|c|c|c|c|c|}
\hline \multirow[b]{2}{*}{ Model } & \multicolumn{2}{|c|}{$\begin{array}{l}\text { Unstandardized } \\
\text { Coefficients }\end{array}$} & \multirow{2}{*}{$\begin{array}{l}\text { Standardized } \\
\text { Coefficients } \\
\text { Beta }\end{array}$} & \multirow[b]{2}{*}{$\mathrm{t}$} & \multirow[b]{2}{*}{ Sig. } & \multicolumn{2}{|c|}{$\begin{array}{l}\text { Collinearity } \\
\text { Statistics }\end{array}$} \\
\hline & B & $\begin{array}{l}\text { Std. } \\
\text { Error }\end{array}$ & & & & Tolerance & VIF \\
\hline 1 (Constant) & $\begin{array}{l}- \\
185,852\end{array}$ & 48,895 & & $-3,801$ & ,019 & & \\
\hline CR & 206,514 & 30,690 & 1,048 & 6,729 & ,003 & ,816 & 1,226 \\
\hline ROE & 148,279 & 79,151 & ,292 & 1,873 & , 134 & ,816 & 1,226 \\
\hline
\end{tabular}

a. Dependent Variable: EPS

Model regresi multicollinear gratis adalah jika memiliki toleransi Ini lebih besar dari 0,1 , dan nilai VIF kurang dari 10. Berdasarkan tabel di atas, nilai VIF untuk setiap variabel yang diteliti dapat dianggap sebagai berikut.

1) Karena nilai VIF dari variabel CR adalah $1226<10$, variabel CR adalah Ini terjadi dalam multikolinieritas.

2) Nilai VIF dari variabel ROE adalah $1226<10$, jadi variabel CR tidak Cegah multikolinearitas.

Data yang digunakan untuk uji multikolinieritas ini adalah data variabel independen. Variabel-variabel ini menunjukkan bahwa semua variabel independen memiliki nilai toleransi kurang dari 1 VIF, nilai kurang dari 10, sehingga tidak ada multikolinieritas dalam model ini dan dapat digunakan.

\section{d. Hasil Uji heteroskedastisitas}

Uji heteroskedastisitas menentukan apakah ada ketidakseimbangan antara nilai residu dan nilai-nilai lain yang diamati dalam model regresi. Model regresi yang baik adalah heteroskedasticheskim atau tidak mengembangkan hesteroskedastasis menggunakan tes glasial.

Diagram difusi dapat digunakan untuk menentukan tes historis. Titik-titik yang terbentuk harus tersebar secara acak di atas dan di bawah angka 0. Pada sumbu Y. Jika kondisi ini dipenuhi, tidak ada heterogenitas ester dan model regresi dimungkinkan. Hasil uji heteroskedastisitas menggunakan diagram difusi disajikan pada Gambar 4.4 di bawah ini.

Gambar 4.4

Grafik Uji Heteroskedastisitas

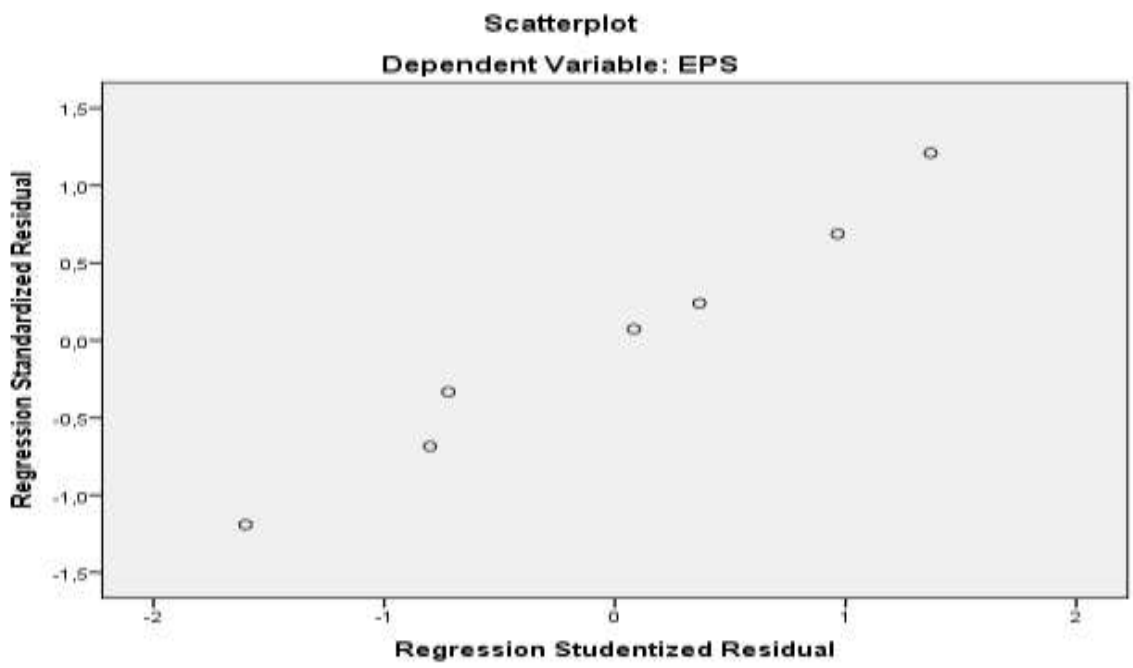




\section{Analisis regresi linier berganda}

Untuk melihat efek antara rasio saat ini (CR) dan laba atas ekuitas (ROE) untuk EPS (respons terhadap saham), kami memproses data dari penelitian ini untuk mendapatkan hasil berikut:

Tabel 4.6

Hasil Regresi Linier Berganda

\section{Coefficients $^{a}$}

\begin{tabular}{|c|c|c|c|c|c|}
\hline \multirow[t]{2}{*}{ Model } & \multicolumn{2}{|c|}{$\begin{array}{l}\text { Unstandardized } \\
\text { Coefficients }\end{array}$} & \multirow{2}{*}{\begin{tabular}{|l} 
Standardiz \\
ed \\
Coefficient \\
s \\
Beta
\end{tabular}} & \multirow[t]{2}{*}{$t$} & \multirow[t]{2}{*}{ Sig. } \\
\hline & $B$ & $\begin{array}{l}\text { Std. } \\
\text { Error }\end{array}$ & & & \\
\hline $\begin{array}{l}\text { (Constant } \\
1 \text { CR } \\
\text { ROE }\end{array}$ & $\begin{array}{l}- \\
185,852 \\
206,514 \\
148,279\end{array}$ & $\begin{array}{l}48,895 \\
30,690 \\
79,151\end{array}$ & $\begin{array}{l}1,048 \\
, 292\end{array}$ & $\begin{array}{l}3,801 \\
6,729 \\
1,873\end{array}$ & $\begin{array}{l}, 019 \\
, 003 \\
134\end{array}$ \\
\hline
\end{tabular}

a. Dependent Variable: EPS

Persamaan Regresi :

$Y=-185,852+206,514 X_{1}+148,279 X_{2}+e$

Atau

Earning Per Share $=-185,852+206,514$ Current Ratio $+148,279$ Return On Equity

Hasil dari Uji Regresi Linier Berganda diatas memberikan pengertian sebagai berikut :

a. - 185,852 Variabel independen ini adalah konstanta yang masuk akal untuk konstanta ini jika CR, ROE maka EPS sebesar - 185,852.

b. Koefisien regresi untuk CR terhadap EPS sebesar 206,514 memiliki arti bahwa apabila semua variabel independennya itu sama dengan nol, maka EPS akan bernilai sebesar - 185,852. Setelah itu koefisien CR bernilai sebesar 206,514 artinya bahwa setiap peningkatan 1 satuan CR, maka EPS akan naik sebesar 206,514.

c. Koefisien regresi untuk ROE terhadap EPS sebesar 148,279 memiliki arti bahwa apabila semua variabel independennya itu sama dengan nol, maka EPS akan bernilai sebesar - 185,852. Setelah itu koefisien ROE bernilai sebesar 148,279 artinya bahwa setiap peningkatan 1 satuan ROE, maka EPS akan naik sebesar 148,279.

\section{Hasil Uji Korelasi}

Tabel 4.7

Hasil uji Koefisien Korelasi

Model Summary

\begin{tabular}{|l|l|l|l|l|}
\hline Model & $R$ & $\begin{array}{l}\text { R } \\
\text { Square }\end{array}$ & $\begin{array}{l}\text { Adjusted } \\
\text { R Square }\end{array}$ & $\begin{array}{l}\text { Std. Error of } \\
\text { the Estimate }\end{array}$ \\
\hline 1 &, $960^{\mathrm{a}}$ & 0,921 & 0,881 & 11,83796 \\
\hline
\end{tabular}

a. Predictors: (Constant), ROE, CR

b. Dependent Variable: EPS 
Berdasarkan tabel output di atas, tampak bahwa koefisien $\mathrm{R}$ atau korelasi adalah 0,960. Nilai ini menunjukkan bahwa hubungan antara variabel $C R$ dan $R O E$ dalam EPS sangat kuat.

\section{Hasil Uji Koefisien Determinasi}

Faktor-faktor penentu digunakan untuk menentukan hubungan pengaruh variabel independen terhadap variabel dependen.

Tabel 4.8

Hasil Uji Koefisien Determinasi

Model Summary ${ }^{b}$

\begin{tabular}{|l|l|l|l|l|l|}
\hline Model & $\mathrm{R}$ & $\begin{array}{l}\mathrm{R} \\
\text { Square }\end{array}$ & $\begin{array}{l}\text { Adjusted } \\
\text { Square }\end{array}$ & $\begin{array}{l}\text { Std. Error of the } \\
\text { Estimate }\end{array}$ \\
\hline 1 &, $960^{\mathrm{a}}$ & 0,921 & 0,881 & 11,83796 \\
\hline
\end{tabular}

a. Predictor: (persistent), ROE, CR

b. Variabel Tanggungan: EPS

Berdasarkan tabel di atas, dengan memplot koefisien determinasi $\mathrm{R}$ kuadrat (R2), nilai R2 mewakili sejauh mana variasi $Y$ disebabkan oleh $X$, nilai $R 2$ diperoleh dari hasil perhitungan 0,921 atau 92,1\%. Dengan kata lain, variabel rasio likuiditas saat ini (CR) dan return on equity (ROE) memengaruhi laba per saham sebesar 0,921, sedangkan sisanya 7,9\% dipengaruhi oleh faktor lain di luar model.

Kuadrat khusus $\mathrm{R}$ adalah nilai yang disesuaikan $\mathrm{R} 2$, yang menghitung nilai yang disesuaikan dari $R$ kuadrat 0,8181 atau $88,1 \%$ untuk membawa gambar lebih dekat dengan kualitas model navigasi. Dengan kata lain, variabel current ratio (CR) dan return on equity (ROE) menyebabkan 0,881 untuk EPS, sedangkan sisanya $11,9 \%$ dipengaruhi oleh faktor lain di luar model.

\section{Pengujian Hipotesis}

Hasil dari hipotesis penelitian ini terdiri dari uji parsial atau t dan laba per tindakan (EPS) dari pengujian simultan atau $\mathrm{F}$.

a. Uji Parsial (Uji T)

T-test digunakan untuk memeriksa signifikansi pengaruh masing-masing variabel independen (rasio saat ini dan laba atas ekuitas) pada variabel dependen (laba per saham).

Tabel 4.9

Hasil Perhitungan Uji t

\section{Coefficients $^{\mathrm{a}}$}

\begin{tabular}{|l|l|l|l|l|l|}
\hline Model & \multicolumn{2}{|l|}{$\begin{array}{l}\text { Unstandardized } \\
\text { Coefficients }\end{array}$} & $\begin{array}{l}\text { Standardiz } \\
\text { ed } \\
\text { Coefficient } \\
\text { s }\end{array}$ & & Sig. \\
\cline { 2 - 4 } & B & $\begin{array}{l}\text { Std. } \\
\text { Error }\end{array}$ & Beta & & \\
\hline $\begin{array}{l}\text { (Constant } \\
\text { ) }\end{array}$ & $-185,852$ & 48,895 & & $-3,801$ &, 019 \\
CR & 206,514 & 30,690 & 1,048 & 6,729 &, 003 \\
ROE & 148,279 & 79,151 &, 292 & 1,873 &, 134 \\
\hline
\end{tabular}

a. Dependent Variable: EPS 
Berdasarkan koefisien keluaran di atas, diketahui bahwa nilai koefisien regresi untuk variabel independen, yaitu rasio lancar dan pengembalian ekuitas, adalah sebagai berikut:

1. Rasio lancar (X1) dengan laba per saham (Y)

Atas dasar tabel di atas, variabel CR di atas memperoleh angka 6729 sedangkan

Tabel dengan tingkat kepentingan $5 \%$ dan derajat kebebasan $(\mathrm{dk})=\mathrm{nk}=7$ $2=5$ sama dengan tahun 2015. Membandingkan thitung (6 729)> ttabel (2015), kita dapat menyimpulkan bahwa itu milik zona pelepasan H0. (H0 diizinkan, dan Ha ditolak). Seperti yang Anda lihat pada tabel di atas, Anda dapat melihat bahwa level signifikansi adalah 0,003. Ini berarti bahwa angka ini di bawah tingkat signifikansi $(0,05>0,003)$. Kita dapat menyimpulkan bahwa perubahan $\mathrm{CR}$ sebagian berpengaruh. EPS berubah.

2. Pengembalian ekuitas (X2), laba per saham (Y)

Berdasarkan tabel di atas, variabel ROE lebih tinggi dari 188873, dengan tingkat signifikansi $5 \%$ dan array dengan derajat kebebasan $(\mathrm{dk})=\mathrm{nk}=7-2$ $=5$, seperti pada tahun 2015. tcount $(1.887)<$ ttable (2.015), kita dapat menyimpulkan bahwa itu milik wilayah deviasi $\mathrm{Ha}$ (deviasi Ha, deviasi $\mathrm{H}$ ). Seperti yang Anda lihat pada tabel di atas, Anda dapat melihat bahwa level signifikansi adalah 0,134 . Ini berarti bahwa angka ini di bawah tingkat signifikansi $(0,05>0,134)$, sehingga kita dapat menyimpulkan bahwa mengubah ROE berfungsi, tetapi tidak penting untuk perubahan tersebut. EPS.

b. Uji Simultan (Uji F)

Uji $F$ digunakan untuk menguji signifikansi efek antara variabel independen (rasio saat ini dan laba atas ekuitas) pada variabel dependen (laba per saham).

Tabel 4.10

Hasil Perhitungan Uji F

ANOVA $^{\mathrm{a}}$

\begin{tabular}{|c|c|c|c|c|c|}
\hline Model & $\begin{array}{|ll|}\text { Sum } & \text { of } \\
\text { Squares } & \\
\end{array}$ & $d f$ & \begin{tabular}{|l} 
Mean \\
Square
\end{tabular} & $F$ & Sig. \\
\hline $\begin{array}{l}\text { Regression } \\
\text { Residual } \\
\text { Total }\end{array}$ & $\begin{array}{l}6522,831 \\
560,549 \\
7083,381\end{array}$ & $\begin{array}{l}2 \\
4 \\
6\end{array}$ & \begin{tabular}{|l|}
3261,416 \\
140,137
\end{tabular} & 23,273 &, $006^{b}$ \\
\hline
\end{tabular}

a. Variabel Tanggungan: EPS

b. Predictor: (persistent), ROE, CR

Berdasarkan hasil uji ANOVA di atas, nilai 23.273 diperoleh dengan tingkat signifikansi 0,006 . Untuk ftabel dengan nilai $5 \%$ dan df $1=k=2$, df $2=n k-1=7-$ $2-1=4$, ini akan menjadi ftabel 4737. Dalam keadaan ini, ketika fcount lebih besar dari ftabel $(23.273>6.944)$, jika nilainya signifikansi 0,006 kurang dari 0,05 , kita bisa menafsirkan bahwa HO menyimpang dan Ha menyimpang. Dengan demikian, kita dapat menyimpulkan bahwa rasio saat ini dan tingkat pengembalian modal memiliki dampak signifikan terhadap laba per saham.

\section{Pembahasan}

Berdasarkan analisis data di atas, rasio likuiditas saat ini (CR) dan ROE (laba atas investasi) pada laba per saham (PTS) di PT dipengaruhi oleh tes. Wijaya Karya Tbk periode 2011-2017, beberapa faktor dapat dijelaskan dalam penelitian ini.

1. Pengaruh koefisien saat ini (CR) pada PES (EPS)

Berdasarkan tabel 4.12 di atas, penelitian ini menunjukkan pengaruh rasio lancar (CR) terhadap laba per saham (EPS) dengan tingkat signifikansi 0,003. Ini berarti bahwa 
indikator ini berada di bawah level signifikansi (CR). 0,05>0,003), yang menunjukkan bahwa CR memiliki pengaruh signifikan terhadap EPS. Peningkatan utang mempengaruhi jumlah laba bersih yang tersedia bagi pemegang saham, termasuk pendapatan yang diterima, karena kewajiban membayar utang lebih diutamakan daripada distribusi keuntungan.

2. Pengaruh laba atas ekuitas (ROE) terhadap laba per saham (EPS)

Berdasarkan tabel 4.12 di atas, penelitian ini menunjukkan pengaruh pengembalian atas investasi (ROE) terhadap laba per saham (EPS) dengan tingkat signifikansi 0,134. Ini berarti bahwa indikator ini lebih tinggi dari tingkat signifikansi $(0(05>0.134))$. ROE tidak berpengaruh signifikan terhadap BPA. Ini berarti bahwa laba atas ekuitas yang rendah tidak akan memengaruhi investor. Jika jumlah saham berkurang, laba bersih per saham pada prinsipnya bisa tinggi, tetapi jika jumlah sahamnya besar, sebaliknya beredar meningkat, eps menjadi kecil.

3. Pengaruh rasio saat ini (CR) dan laba atas ekuitas (ROE) terhadap laba per saham (EPS)

Berdasarkan tabel 4.13 di atas, penelitian ini menunjukkan bahwa pengaruh rasio lancar (CR) dan return on equity (ROE) memiliki dampak signifikan terhadap laba per saham (EPS). Fhitung $>$ Ftabel, karena nilai $F$ yang dihitung untuk variabel Current Ratio (CR) dan Return On Equity (ROE) 23.273 lebih besar dari $F$ tabel 6,944, 0,006 kurang dari 0,006 berdasarkan SPSS $20(0,006<0,0$

\section{E. KESIMPULAN}

1. Pengaruh rasio lancar (CR) pada laba per saham (EPS) PT. Wijaya Karya Tbk.

Berdasarkan hasil analisis data, ditentukan bahwa totalnya adalah 6,729 dengan nilai signifikan 0,003 dan tabel 2015. Karena thitung $>$ ttabel $(6,729>2,015)$ dan signifikan $(0,003<0,05)$, HO diterima, Ha ditolak. Karena itu kami dapat menyimpulkan bahwa rasio saat ini (CR) memiliki pengaruh yang signifikan terhadap laba per saham (EPS).

2. Pengaruh laba atas ekuitas (ROE) terhadap laba per saham (EPS) PT. Wijaya Karya Tbk.

Berdasarkan hasil analisis data, ditentukan bahwa jumlahnya adalah 1.873 dengan nilai signifikan 0,134 dan tabel 2015. Sebagai thitung $>$ ttabel $(1,873<2,015)$ dan signifikan $(0,134>0,05)$, maka $\mathrm{HO}$ ditolak, Ha diterima. Karena itu kita dapat menyimpulkan bahwa laba atas ekuitas (ROE) secara parsial, tetapi tidak signifikan, mempengaruhi laba per saham (EPS).

3. Pengaruh rasio saat ini (CR) dan laba atas ekuitas (ROE) terhadap laba per saham (EPS)

Berdasarkan hasil analisis data, tentukan bahwa Fcount adalah 23.273 dengan nilai signifikan 0,006 dan array 6,944. Karena Fhitung > Ftabel $(23.273>6.944)$ dan signifikan $(0,006<0,05)$. Oleh karena itu kita dapat menyimpulkan bahwa variabel Current Ratio (CR) dan Return On Equity (ROE) pada saat yang sama memiliki pengaruh yang signifikan terhadap laba per saham (EPS). 


\section{DAFTAR PUSTAKA}

Abdul Kadim, K., \& Nardi Sunardi, S. (2018). Determinant Of Company's Likuidity And It's Implications On Financial's Performance Of Ritail Trade Company's In Indonesia At The Period Of 2008-2017. Global and Stockhastic Analysis, 5(7), 235-247.

Abdul Kadim, K., \& Nardi, S. (2018). Eviews Analysis: Determinant Of Leverage And Company's Performance. Global and Stochastic Analysis (GSA), 5(7), 249-260.

Bringham dan Houtson. 2011. "Dasar - Dasar Manajemen Keuangan", edisi kesebelas, buku pertama, Penerbit : Salemba Empat, Jakarta.

Darsono. 2006. "Manajemen Keuangan Pendekatan Praktis", Nusantara Consulting Jakarta.

Duwi Priyatno. 2012. "Belajar Cepat Olah Data Statistik dengan SPSS", CV, Andi Offset, Yogyakarta.

Fadli, Achmad Agus Yasin. 2017. "Analisis Kinerja Keuangan Ditinjau Dari Aspek Likuiditas dan Rentabilitas Ekonomi Pada PT. ASTRA ARGO LESTARI Tbk." Universitas Pamulang

Fahmi, Irham. 2012. "Pengantar Manajemen Keuangan", Cetak Kesatu, Penerbit: ALFABETA, CV, Bandung

Ghozali, Imam. 2011. "Aplikasi Analisis Multivariate Dengan Program SPSS". Semarang: Badan Penerbit Universitas Diponegoro.

Hanafi M. Mamduh. 2010. "Manajemen Keuangan", Edisi Pertama, Cetakan Ketiga, Penerbit: HPFE, Yogyakarta.

James C. Van Home dan John M Wachowiez, Jr.2012. "Prinsip - Prinsip Manajemen Keuangan", Edisi 13, Salemba Empat, Jakarta

Kadim, A., \& Sunardi, N. (2019). Pengaruh Profitabilitas, Ukuran Perusahaan Terhadap Leverage Implikasi Terhadap Nilai Perusahaan Cosmetics and Household yang terdaftar di Bursa Efek Indonesia. Jurnal SEKURITAS (Saham, Ekonomi, Keuangan dan Investasi), 3(1), 22-32.

Kasmir. 2010. "Pengantar Manajemen Keuangan", Edisi Pertama, Cetakan Kedua, Penerbit: Kencana Prenada Media Group, Jakarta

Kasmir. 2015. "Analisis Laporan Keuangan”, Jakarta: PT Raja Grafindo Persada.

Martono dan Agus Harjito. 2010. "Manajemen Keuangan", Ekonosia. Yogyakarta

Munawir, S. 2013. "Analisis Laporan Keuangan', Cetakan Kelima Belas, Penerbit Liberty, Yogyakarta

Sugiyono. 2012. "Metode Penelitian Kuantitatif Kualitatif dan R\&D", Cetakan Keempat, Penerbit: ALFABETA, CV, Bandung

Sunardi, N. (2019, January). Relevansi Struktur Kepemilikan Tentang Profitabilitas Dan Nilai Perusahaan (Studi pada Industri Manufaktur yang Terdaftar di Bursa Efek Indonesia Periode 2010-2017). In Proceedings (Vol. 1, No. 1).

Sunardi, N., \& Hendarsah, D. (2019). Faktor-Faktor yang Mempengaruhi Laba dan Dampaknya pada Nilai Perusahaan (Studi Kasus Pada Perusahaan BUMN Bidang Kontruksi Yang Terdaftar Di Bursa Efek Indonesia tahun 20082017). Jurnal SEKURITAS (Saham, Ekonomi, Keuangan dan Investasi), 3(1), 121.

Sunardi, N., \& Permana, R. D. I. (2019). Faktor-Faktor Yang Mempengaruhi Harga Saham Dan Dampaknya Pada Nilai Perusahaan (Studi Kasus pada Perusahaan Sub Sektor Pertambangan Minyak dan Gas Bumi yang Terdaftar di Bursa Efek www.idx.co.id Indonesia Tahun 2013-2017). JIMF (Jurnal IImiah Manajemen Forkamma), 2(2).

www.indosaja.com

www.wika.co.id

www.wikipedia.com 